\title{
PRACA I INNOWACYJNOŚĆ \\ W WARUNKACH ZARZĄDZANIA ALGORYTMICZNEGO I DOMINACJI TECHNOLOGII CYFROWYCH. WYBRANE KONTEKSTY KULTUROWE, SPOŁECZNE I EKONOMICZNE
}

\begin{abstract}
AвSTRACT. Drozdowicz Jarema, Praca i innowacyjność w warunkach zarządzania algorytmicznego i dominacji technologii cyfrowych. Wybrane konteksty kulturowe, społeczne i ekonomiczne [Labor and Innovation in the Era of Algorithmic Management and the Domination of Digital Technologies. Selected Cultural, Social and Economic Contexts]. Studia Edukacyjne nr 58, 2020, Poznań 2020, pp. 47-67. Adam Mickiewicz University Press. ISSN 1233-6688. DOI: 10.14746/ se.2020.58.3
\end{abstract}

The issue of algorithmic management is constituted by an array of conditions, socio-cultural and economic ones seeming to be the most important today. This article explores selected aspects and phenomena related to creativity, innovation and labor in the age of digital technologies and the domination of algorithms. The key problem in this case is the digitalization of labor, a phenomenon which also affects the creative processes and innovation. The notion of creativity shifts today towards a specific model of labor, based on and conditioned by the use of digital tools and often managed by machines, i.e. algorithms. Algorithmic labor is considered here as a social and cultural problem. The text investigates selected effects of these tendencies and highlights the important emerging issues, like the culture of incompetence for example. The outcome of this research might be used not just to improve the digital solutions in that regard, but rather to recompose the significant ideas that constitute the reflection on human agency in general.

Key words: algorithmic management, ICT, education, digital nomad, gig economy, labor theory

Akt kreacji dokonywany jest niezmiennie przez aktora społecznego, wykraczającego za każdym razem poza narzucane mu ograniczenia. Innowacja, będąca efektem tego procesu, jest zatem swoistym zakwestionowaniem nie tylko technologicznego, ale też społeczno-ekonomicznego status quo. Takie 
założenie stoi w pewnej sprzeczności z kilkoma tradycjami intelektualnymi żywymi nadal w naukach społecznych, a dotykających przy tym problemu sprawczości. Pierwszą z nich będzie tradycja socjologiczna lokująca swe korzenie w myśli Emila Durkheima. Zgodnie z wykładnią durkheimowską, jednostka pozostaje pod wpływem zobiektywizowanych w swej postaci norm i sił społecznych, przystosowując się do roli wyznaczonej jej przez zbiorowość, do której przynależy. Parasol normatywny, jaki społeczeństwo rozciąga nad jednostką stanowi jednocześnie zbiór dyrektyw odnoszących się do wartości, praktyki i sposobów obchodzenia się ze zjawiskami wobec niej zewnętrznymi. Durkheim przyznaje jednak, że „nie należy zakładać z góry, że jakaś praktyka czy instytucja ma charakter konwencjonalny"1. Zasady życia społecznego podlegają bowiem zmianom nawet $\mathrm{w}$ ściśle sformalizowanych systemach społecznych. Tym, co w socjologii, wyrosłej na gruncie teorii autora Zasad metody socjologicznej, pozostaje ważne w kwestii określenia miejsca jednostki w życiu zbiorowym jest strukturalne powiązanie faktów społecznych w system regulujący działania podmiotu. $\mathrm{W}$ takim układzie podmiot zredukowany zostaje w dużej mierze do wykonawcy systemowych reguł działania, a przez to utrwalającym społeczne wzorce w wymiarze relacyjnym. Durkheim uważał, że taką rolę pełni też edukacja. Jak twierdził, to właśnie dzięki edukacji społeczeństwo odtwarza nieustannie warunki swojego istnienia ${ }^{2}$. Nauczanie i systemy szkolnictwa funkcjonują $\mathrm{w}$ jego przekonaniu nie tylko na zasadzie moralnego regulatora i narzędzia formowania odpowiedzialnych społecznie jednostek, zdolnych do samodzielnego działania zgodnego z ustalonym $\mathrm{w}$ danej zbiorowości schematem normatywnym. Ich rola jest znacznie donioślejsza. Mają za zadanie utrzymywać system społeczny w stanie równowagi i umacniać podstawy jego dalszego trwania.

Procesy twórcze zachodzące $\mathrm{w}$ społeczeństwie byłyby $\mathrm{w}$ perspektywie durkheimowskiej wynikiem rozwoju zachodzącego na poziomie całej struktury, nie zaś oddolnej inicjatywy świadomych swego potencjału podmiotów ${ }^{3}$. Rozwój społeczny, stymulowany przez edukację (zwłaszcza sformalizowany system szkolnictwa), zachodzi tak w rejestrze moralności, jak i społecznych instytucji oraz ról przyjmowanych przez podmioty w procesach przystosowawczych wobec otoczenia społecznego. Jednostki skazane są niejako w tym przypadku na poruszanie się $\mathrm{w}$ granicach społecznych jedynie tak dalece, jak zbiorowo podzielane normy na to pozwalają. Durkheima wizja społeczeństwa nie pozostawiała zatem zbyt wiele miejsca na kreatywne działania pod-

\footnotetext{
${ }^{1}$ E. Durkheim, Zasady metody socjologicznej, Warszawa 1968, s. 57.

2 S. Lukes, Durkheim, Warszawa 2012, s. 134.

${ }^{3}$ W. Watts Miller, Creativity: a key Durkheimian concern and problematic, European Journal of Social Sciences, 2017, 55(2), s. 17-40.
} 
miotu rozumianego jako byt niezależny wobec zbiorowych oczekiwań. Człowiek pozostawałby w tej klasycznej wizji socjologicznej głównie elementem szerszego układu reguł odnoszących się do procesów wytwarzania i przetwarzania rzeczywistości przefiltrowanej niezmiennie przez makroperspektywę właściwą danej wspólnocie.

Drugim rodzajem naukowego ujęcia podzielającego podobny rodzaj determinizmu byłaby amerykańska tradycja partykularyzmu kulturowego i wyrosła bezpośrednio na niej szkoła psychologii kulturowej. Jej intelektualny patron, to jest Franz Boas, sugerował, iż uwarunkowania kulturowe kształtują uwewnętrzniony przez jednostki zespół tak wzorców postępowania, jak i światopoglądów odzwierciedlających kluczowe idee w danej kulturze $^{4}$. Esencjonalny charakter tych idei przenika wszystkie obszary życia w takiej społeczności. Stają się one swoistym motywem przewodnim zarówno w sferze instytucjonalnej, jak i subiektywnie podzielanych schematów myślenia o rzeczywistości. Patrzymy zatem na świat niezmiennie oczyma kultury, w której przyszło nam żyć i której zasady, poprzez wychowanie w niej, wpłynęły bezpośrednio na nasze jednostkowe działania, wybory i samodzielne inwencje. Jak konstatuje w tej materii Boas, „,odkrycia mogą zostać dokonane jedynie w środowisku, w którym znajduje się człowiek" ${ }^{\prime 5}$. To otoczenie rozwija przed podmiotem szablon możliwości w kwestii tworzenia, a ludzka inwencja zostaje jedynie przezeń zainspirowana do aktu kreacji. Tak zdaniem Boasa odkryto zdolność do rozpalania ognia za pomocą pierwszych prymitywnych narzędzi - poniekąd przypadkiem pierwsza iskra została zaprószona, kiedy pocierano ze sobą dwa kawałki drewna. Z kolei obchodzenie się z różnymi materiałami sprawiło, iż ludzie zaznajomili się z faktami z obszaru chemii i fizyki. Wynalazek nauki jest w tym kontekście wynikiem ewolucyjnego rozwinięcia obserwacji poczynionych przez człowieka w świecie przyrody ${ }^{6}$. Problem jednak w tym, że każda kultura czyni ten sam krok w nieco odmiennym tempie i nadaje czynionej wokół tego odkrycia kulturowej nadbudowie nieco inne i specyficzne dla danego kontekstu kształty.

Trzecią tradycją, stojącą niejako $\mathrm{w}$ kontrze do omawianego tu problemu kreacji i sprawczości człowieka, jest bowiem ujęcie psychologiczne, zwłaszcza utrzymane w konwencji psychoanalitycznej. Zagrożeniem dla osobowości, a dokładniej rzecz biorąc dla przebiegu procesu jej budowy, bywają $\mathrm{w}$ tej perspektywie zewnętrzne wobec jaźni czynniki stymulujące ten proces. Czynniki takie jak wpływ środowiska społecznego wraz z wszelkimi zaburzeniami z niego wynikającymi, długotrwałe oddziaływanie traumy lub wpływ

\footnotetext{
${ }^{4}$ F. Boas (red.), General Anthropology, Boston - New York - Chicago - Atlanta - Dallas - San Francisco - London 1938.

5 Tamże, s. 239.

${ }^{6}$ Tamże, s. 274.
} 
innych, choć niemniej ważnych dla życia jednostki doświadczeń, stanowią elementy bezpośrednio formujące strukturę osobowości, a przez to też wpływające na relacje interpersonalne. Uwarunkowana psychologicznie rzeczywistość przepełniona zostaje zatem subiektywnymi przeżyciami jednostek i to poprzez aspekt subiektywny należy rozpatrywać ludzkie działania. Determinizm psychologiczny może być tu rozpatrywany w dwóch wariantach. Po pierwsze, czynniki psychologiczne warunkować mogą nasze działanie w tym sensie, iż zawsze kierujemy się najsilniejszym pod względem emocjonalnym czynnikiem. Po drugie natomiast, pewna doza psychologicznej racjonalności może nam podpowiadać podjęcie danego działania zgodnie z dominującą racją, jak chciałby to widzieć między innymi Donald Davidson?. Takie psychologiczne spojrzenie na racjonalne podstawy działania społecznego wiążą się jednak z koniecznością uwzględnienia wszelkich procesów kognitywnych, gdyż „rozum racjonalizuje działanie tylko wtedy, gdy prowadzi nas do tego, co aktor społeczny dostrzegał, lub zdawało mu się, że dostrzega (...)" ${ }^{\prime \prime}$. Powiązanie wymiaru poznawczego z płaszczyzną racjonalności jest zaś dla analizy problemu sprawczości istotne ze względu na konieczność systematyzacji psychologicznych motywów stojących za aktem kreacji.

Homo creator nie kieruje się jednakże jedynie logiką i kalkulacją. Tworzenie czegoś nowego lub dokonanie innowacyjnej zmiany może być na równi z efektem swobodnej gry z kulturową konwencją. Dostrzeżenie kulturotwórczej roli, jaką niesie ze sobą zabawa stanowi skądinąd podstawę formuły, która przez Johana Huizingę uznana zostaje jako jeden $\mathrm{z}$ ważniejszych obszarów ludzkiej sprawczości ${ }^{9}$. Spopularyzowana przez holenderskiego historyka formuła homo ludens stanowi tu antytezę człowieka pracy. Warto w tym miejscu przypomnieć, że dychotomia pracy i zabawy jest dla zachodniego porządku społecznego podstawowym wyznacznikiem kapitalistycznego i przemysłowego sposobu organizacji czasu. Huizinga traktuje niemniej zabawę jako samodzielną kategorię analityczną, uznając przy tym, iż wskazanie na powagę jako drugi biegun dyskusji nie jest w tym przypadku „ani jednoznaczne, ani zasadne" ${ }^{\prime 10}$. Człowiek zabawy jest jednakże istotą wykraczającą poza zwykłe życie, gdyż samo uczestnictwo w zabawie stanowi przeniesienie się "w sferę tymczasowej aktywności o swoistych tendencjach"11. Kulturowa funkcja czasu zabawy polega na chwilowym zawieszeniu ograniczeń codzienności i zezwala na rozegranie nie tylko napięć pojawiających się $\mathrm{w}$ relacjach społecznych, lecz przy zachowaniu pewnych ustalonych reguł gry podważenie

\footnotetext{
7 D. Davidson, Essays on Actions and Events, Oxford 2001.

8 Tamże, s. 3.

9 J. Huizinga, Homo ludens. Zabawa jako źródto kultury, Warszawa 1985.

10 Tamże, s. 17.

${ }^{11}$ Tamże, s. 21.
} 
do pewnego stopnia obowiązującego porządku i jego zmianę. Swoiste zawieszenie norm jest $\mathrm{w}$ zabawie tymczasowe. Podczas zabawy możliwe jest jednak ich przekroczenie na rzecz poszukiwania nowych rozwiązań starych problemów. Dzięki temu zjawisko zabawy może przyjmować dwie podstawowe postaci - walki o coś lub przedstawienia czegoś ${ }^{12}$. W pierwszym z wymienionych przypadków dochodzi do ścierania się sił, których źródła mogą leżeć $\mathrm{w}$ głęboko zakorzenionych kulturowych archetypach, gdzie niczym $\mathrm{w}$ greckiej tragedii odbywa się uświęcona walka, na przykład dobra ze złem. Wynik tej symulowanej walki przesądza niekiedy o układzie sił poza światem zabawy. Zwycięstwo jednej czy drugiej strony jest bowiem usankcjonowane społecznie, niekiedy zaś również politycznie. Zabawowe przeformułowanie tych zależności skutkuje niekiedy przesunięciami w realiach nie będących już grą. W drugim przypadku z kolei mamy do czynienia z reprezentacją. Pamiętajmy, że zabawa poprzez przedstawienie może również stanowić czynnik inicjujący zmianę. Zgodnie z wykładnią teorii dramatu społecznego Victora Turnera, pojawiająca się $w$ trakcie każdego karnawału antystruktura wprawdzie unieważnia na moment dotychczasową dominację określonych grup społecznych, zastępując ją rządami grup znajdujących się zazwyczaj na dole drabiny społecznej ${ }^{13}$.

Wbrew potocznemu osądowi homo ludens nie jest zatem figurą pozbawioną wielkiej kulturowej wagi. Wręcz przeciwnie - jego znaczenie jest o tyle ważne dla procesów kulturotwórczych, iż wprowadzenie elementów ludycznych w rozmaite praktyki społeczne nie tylko je oswaja w kontekście na przykład drwin z instytucji władzy, ale również nadaje im ten rodzaj ambiwalencji, który zezwala na względnie swobodne eksperymentowanie z różnymi wariantami danego zjawiska. Powstająca w ten sposób ontologia użyteczności zbliża homo ludens i homo creator na płaszczyźnie technologicznej. W obu przypadkach mamy do czynienia bowiem z działaniem podmiotu badającego rzeczywistość i własne możliwości jej transformacji. Pole technologiczne, jak i wszelkie inne materialne jego manifestacje unaocznia bardzo dobrze to zjawisko. Pewne rozwiązania $\mathrm{w}$ tej sferze wydają się bowiem lepiej nadawać w danej praktyce, inne natomiast zdają się być całkowicie przestarzałe. Antropologia techniki, jaka wyłania się z owej zależności opiera się na kilku zasadniczych warunkach ${ }^{14}$. Należy do nich zespół indywidualnych i zbiorowych potrzeb, elementy twórcze, właściwe wykorzystanie elementów i materiałów konstrukcyjnych, zorientowanie na cel oraz społecznie podzielany obraz rzeczywistości, w której działanie techniczne zachodzi. Wszystkie te składowe

12 Tamże, s. 28.

13 V.W. Turner, Drama, Fields and Metaphors. Symbolic Action in Human Society, New York 1975.

14 H. Poser, Homo Creator - Technik als philosophische Herausforderung, Wiesbaden 2016, s. 97. 
umieszczone zostają w kontekście kulturowym nadającym im właściwy i czytelny dla uczestników zaangażowanych $\mathrm{w}$ działanie techniczne sens. Stąd też technika odgrywa tu nierzadko rolę swoistego znacznika semiotycznego. Techniczne stają się nie tylko przedmioty, czy czynności, ale także nie dające się wprost obiektywnie opisać wartości i światopoglądy. Człowiek jako istota techniczna nie jest zatem wyłącznie inteligentnym zwierzęciem, które posługuje się narzędziami w celu obróbki otoczenia. Przetwarza on i kreuje owo otoczenie $\mathrm{w}$ wymiarze holistycznym, lub chociażby jedynie czyni to dążąc do ustanowienia określonych porządków we wszystkich aspektach swojego trwania. Badając sposoby wytwarzania przez człowieka pewnych wizji własnych realiów musi uwzględnić również to, jak ludzie postrzegają nie tylko swoje miejsce $\mathrm{w}$ świecie, ale także własne zdolności i możliwości wprowadzania w tych realiach autentycznych zmian i korekt. Rodzi się w ten sposób kolejny z modeli człowieka (swoją drogą traktowany często jako antyteza człowieka zabawy), a mianowicie homo faber.

Współczesny homo faber jest dziś postacią wymagającą nowego rozdania kart kompetencyjnych. Jeden z czynników wymuszających tak radykalne podejście stanowi modernizacja techniczna odnosząca się do szybkiego rozwoju sfery cyfrowej i hegemonii rozwiązań z zakresu technologii telekomunikacyjnych (tzw. ICT). Chodzi tu nie tylko o postępującą dzięki owej modernizacji automatyzację cyklu produkcji i konsumpcji, realizującą się głownie w sferze tak zwanej nowej cyfrowej ekonomii, ale także swoiste odwrócenie się człowieka od sfery naturalnej, w której dotąd funkcjonował i którą przetwarzał na swoje potrzeby. Kondycja ludzka pozostaje bowiem obecnie w dobie cyfryzacji poddana wpływowi procesów automatyzacji w skali, jaka dotąd nie była częścią naszego kolektywnego doświadczenia ${ }^{15}$. Na problem ten wskazuje między innymi Hannah Arendt, mówiąc o dokonującym się współcześnie przeskoku z tego co ludzkie (animal rationale) w sferę typową bardziej dla kondycji zwierzęcej (animal laborans) ${ }^{16}$. Degradacja człowieka na rzecz dowartościowania maszyny jest tu efektem ewolucyjnego procesu, $\mathrm{w}$ ramach którego rozmaite i sprzeczne $\mathrm{z}$ antyczną ideą człowieczeństwa uwarunkowania zaczynają dominować w polu ludzkich odruchów, zastępując filozoficzną refleksyjność. Konstrukcja człowieka wiąże się w jej przekonaniu z możliwością wytwarzania, nie będącego swoją drogą czynnością tożsamą z pojęciem działania. Jak zaznacza na wstępie niemiecka filozof: „praca naszych rąk, w odróżnieniu od pracy naszych ciał (...) wytwarza czystą i niekończącą się różnorodność rzeczy, których suma całkowita konstytuuje ludzką pomysłowość"17.

${ }^{15}$ R. Schmiede, Homo faber digitalis? Zur Dialektik von technischen Vortschritt und Arbeitsorganisation, Mitelweg, 2015, 26(24), s. 42.

${ }^{16}$ H. Arendt, The Human Condition, Chicago - London 1998.

17 Tamże, s. 136. 
Dla Arendt wytwarzanie w obrębie antroposfery poszczególnych fenomenów pociąga za sobą tę konsekwencję, iż wpływ człowieka na sferę naturalną zostaje wytrącony z równowagi, jaka łączyła człowieka w epoce przedprzemysłowej. Warunki nowoczesności sprawiają, że wytwarzanie różni się również od pracy. Ta bowiem wiąże się z bezpośrednim zaspokajaniem potrzeb życiowych, a jej efekty są natychmiast konsumowane. Stąd też nie będąc ani działaniem, ani pracą akt kreacji jest czymś w swej istocie szczególnym. Znaczenie tego faktu jest jednak nieco problematyczne. Różniąc się do człowieka pracy (animal laborans), wytwórca (homo faber) posiada znacznie większy potencjał wpływania na otoczenie naturalne. Może on wytrącić świat naturalny z równowagi na rzecz czysto ludzkiego pragnienia przeformowania tegoż świata. Biologizm człowieka pozostaje $\mathrm{w}$ takim wypadku odseparowany od sfery naturalnej na drodze historycznego rozwoju rozmaitych modeli społecznych, a proces ten $\mathrm{w}$ dużym stopniu zakorzeniony został dzięki formule greckiej polis. W warunkach postprzemysłowych, czy późnej nowoczesności, po raz kolejny zatem człowiek zdolny jest do nakreślenia materialnej granicy pomiędzy własnym ciałem a środowiskiem, w którym owa cielesność się znajduje. Procesy wytwórcze polegają $w$ tym ujęciu na reifikacji1 ${ }^{18}$. Patrząc na kierunki rozwoju najnowszych technologii ICT, głównie sztucznej inteligencji, uwaga ta nabiera nieco złowieszczego wydźwięku. Czy faktycznie, jak chce tego Arendt, współczesny homo faber nie tylko jest niezdolny do dostrzeżenia swojego miejsca w szerszym kontekście naturalnym, ale również, zaślepiony siłą oddziaływania swej techniki, nie dostrzega, iż sam staje się przedmiotem instrumentalizując swoje środowisko? Jest to oczywiście nieco uproszczone spojrzenie na zależności wikłające kondycję człowieka w dobie nowoczesności i tym co następuje po niej. Niemniej, zarysowane przez Arendt zjawisko mechanizacji relacji z naturą jest ważnym spostrzeżeniem.

Cyfrowy homo faber jest postacią, dla której akt kreacji zachodzi przede wszystkim poza wymiarem materialnym. Wytwarzając ciąg zer i jedynek oraz konstruując skomplikowane algorytmy, z których utkana zostaje rzeczywistość startupów i systemów operacyjnych, przyczynia się on do proliferacji przekonania o niezbywalności aspektu niematerialnego w świecie fizykalnym. Domniemana realność tego cyfrowego świata jest, jak nietrudno dostrzec, dla wielu kwestią, która nie podlega dyskusji. Liczni apologeci cyfrowej rewolucji stoją dziś nierzadko na stanowisku, iż nowe technologie, w szczególności wysoko zaawansowane ICT, stanowią nieuchronnie krok konieczny dla dalszego kroku w cyklu rozwoju i niosą ze sobą impuls pozytywnej zmiany społecznej. Podejście to jest klasycznym ewolucyjnym, ale też znacznie uproszczonym, rozumowaniem na temat charakteru oraz kie-

${ }^{18}$ Tamże, s. 139. 
runku dynamiki, jaka cechuje każdą historyczną zmianę dokonującą się tak na płaszczyźnie społecznej, jak i kulturowej. Wychodzi się w ramach tego nurtu bowiem z założenia, że „ewolucja dokonująca się na tej planecie stanowi historię uświadamiania sobie coraz to nowszych możliwości tworzywa, z którego ziemia jest wykonana (...), a mianowicie życia"19. Idealistyczne i progresywistyczne nastawienie reprezentowane przez takich autorów, jak między innymi David Pearce i Eric Drexler opiera się na wierze w to, że losy człowieka i maszyny zostały nierozerwalnie połączone, a optymistycznie interpretowana wspólna przyszłość obu bytów może przybierać jedynie ponadbiologiczny i transhumanistyczny format.

Teza mówiąca o osiągniętej obecnie lub w niedalekiej przyszłości technologicznej zdolności wzniesienia się człowieka ponad sferę naturalną jest wspólnym mianownikiem różnych odmian transhumanizmu (znanego także jako $h+$ lub humanity+). Jako nurt współczesnej myśli filozoficznej transhumanizm jest jednak formułą złożoną z różnych propozycji rozwiązania problemu przekroczenia cielesnych ograniczeń właściwych naszemu gatunkowi. Może być on rozpatrywany zarówno jako filozofia (a więc kolejna odmiana humanizmu), jak również jako swoisty światopogląd, ruch społeczny, ale też po prostu zespół poglądów związanych z określoną wizją rozwoju ludzkości, w której to rola technologii ulega znaczącemu dowartościowaniu. Fascynująca wizja transhumanistycznej przyszłości wydaje się być podzielana przez wielu zwolenników cyfrowych rewolucji. Trudno przecież nie zgodzić się z dość zdroworozsądkowym twierdzeniem, potwierdzanym przecież przez potoczne obserwacje, że rozwój ludzkości zawsze wiąże się z wyparciem przez nową jakość starych technologii. Kluczem jednak do zrozumienia debat toczonych wokól transhumanizmu jest niemniej problem granic, które definiują zdolność człowieka do obsługiwania coraz bardziej wymyślnych urządzeń. Czy zatem szare komórki homo sapiens zdolne będą do zmierzenia się z kwantowym mózgiem komputera przyszłości? Bądź co bądź obydwa narzędzia opierają się na tej samej zasadzie przesyłu sygnałów elektrycznych, jednakże porównanie ich potencjału jest całkowicie niewspółmierne. Pytanie to rodzi obawy o możliwość nie tyleż fizycznej (manualnej), co kognitywnej umiejętności rozpoznania zakresu szans, jakie dają najnowsze i najbardziej zaawansowane technologie. Winniśmy zatem zastanowić się, czy rozpoznanie gdzie leżą granice poznawcze człowieka jest niezbędne oraz czy ich przekroczenie daje nam jakiś istotny wkład edukacyjny w rozwój nas samych jako refleksyjnych podmiotów.

Problem ten naświetla Peter Sloterdijk, zmagając się z filozofią nietzscheańską i myślą Martina Heidegerra. Sloterdijk, wychodzi z założenia, że hu-

${ }^{19}$ J. Huxley, Transhumanism, Journal of Humanistic Psychology, 1968, 8(1), s. 73. 
manizm stanowi formę mediacji pomiędzy ludźmi, gdyż „to telekomunikacja zawarta w medium jakim jest druk umożliwia zawiązanie się przyjaźni"20. Epistolarna natura więzi międzyludzkich poddana zostaje jednakże obecnie niełatwej próbie. Współczesna komunikacja, czy też nawet rozumiana jedynie jako czynność pisania książki, przypomina bowiem wysyłanie intymnego listu bez sprecyzowanego adresata ${ }^{21}$. Opierając się na tej tezie, zarysowuje on pewną mapę mentalną, na której źródło ludzkich ograniczeń umiejscowione zostaje poza interakcyjnym stanowieniem społeczeństwa. Więź narodowa bazująca na literackim humanizmie nie jest już w jego przekonaniu dłużej zdolna do utrzymania ani wspólnoty idei państwa narodowego, ani do wytworzenia języka zdolnego wyrazić zbiorowo podzielane cele. Niemały wpływ na to zjawisko miało pojawienie się nowych mediów w drugiej połowie XX wieku. Zdaniem Sloterdijka bowiem, „współczesne społeczeństwa mogą wytwarzać swoją syntezę polityczną i kulturową jedynie marginalnie poprzez literaturę, pisanie listów, czy media humanistyczne" ${ }^{22}$. Nowy format społecznego trwania oparty na nowych narzędziach komunikacji wymazał także stary typ edukacji i kształcenia oparty na masowej nauce piśmiennictwa i admiracji dobrego literackiego stylu. Umiejętność formułowania wypowiedzi o charakterze wysublimowanej ekspresji myśli nie wydaje się obecnie przydatna w obliczu imperatywu szybkości, skrótowości i memicznego przekazywania uproszczonych do maksimum treści. Rodzi to obecnie dwojaki rodzaj nacisku na podmioty przywiązane do humanizmu starej daty. Jeden z nich możemy zidentyfikować jako nacisk wiążący, drugi zaś - wyzwalający. Obie kategorie zidentyfikować możemy z procesami uspołecznienia z jednej strony, z drugiej zaś - „bestializacji”23. Dynamika dychotomii tych dwóch czynników naciskających na podmiot nie jest jednak ustalona, jakkolwiek zostaje ona wyrażona w sensie historycznych ciągów przewagi jednej idei nad drugą. Można nią mianowicie sterować i projektować jej sfery dominacji na kształt parków, w których przechadzający się spacerowicze uczą się wybranych kompetencji w wybranych przez siebie miejscach. Nowoczesność wymusza na nas nieustanne dbanie o zachowanie optymalnej dla ludzi zgodności z wyobrażeniem o idealnej równowadze cechującej ludzką naturę. Techniki zapewniające ten skonstruowany społecznie dobrostan są dla Sloterdijka kluczową zmienną w procesie historycznym. Wyłanianie się na drodze tego procesu kolejnych niespodziewanych zazwyczaj przeszkód czyni z ludz-

20 P. Sloterdijk, Rules for the Human Zoo: a response to the Letter on Humanism, Environment and Planning, 2009, 27, s. 12.

21 Tamże, s. 13.

22 Tamże, s. 14.

${ }^{23}$ Sloterdijk rekonstruując krytycznie w gruncie rzeczy myśl Martina Heideggera, wyraźnie wykazuje w tym miejscu inspiracje tradycyjnym strukturalizmem, przyjmując za dane dynamiczne ścieranie się kategorii natury i kultury. 
kiego życia nieustanną walkę o oswojenie dzikości i przekroczenie naturalnej bariery rozwoju. Tak też formowany jest $\mathrm{w}$ dużym uproszczeniu nietscheański Übermensch - jako postać, której humanizm zdolny jest do wyjścia poza pętający człowieka i z gruntu deterministyczny funkcjonalizm ${ }^{24}$.

Zdigitalizowany postęp realizowany jest zasadniczo na dwa sposoby, wynikające z natury cyfrowych technologii - w obszarze sprzętu i fizycznych narzędzi służących wymianie informacji (hardware) oraz oprogramowania napędzającego te narzędzia i regulującego ich działanie (software). W kontekście materialnych i niematerialnych efektów procesów twórczych podział ten staje się istotny także jako znacznik semiotyczny dla innych niż cyfrowe działań kreacyjnych. Oznacza to, że każda forma działania zorientowanego na wytwarzanie czegoś nowego lub zmianę obowiązujących zasad rozpatrywana jest nierzadko jako specyficzny rodzaj komunikatu, na podobieństwo polecenia wprowadzanego do maszyny. Twórcze zamierzenia rozumiane są $\mathrm{w}$ takim przypadku w kategoriach poprawności kodu binarnego. Oznacza to, że aby akt twórczy mógł zaistnieć, twórca dysponować musi określonym zestawem nie tylko kompetencji technicznych w danej dziedzinie, lecz także zestawem kompetencji semiotycznych, których realizacja zachodzi na płaszczyźnie kultury. Ów kulturowy software jest wgrywany w człowieka na drodze enkulturacji i socjalizacji. Tym samym, każde działanie twórcze zawiera się w partykularnym i definiowanym kontekście. Problematyczne niemniej staje się w tym ujęciu jego zrekonstruowanie na tle tendencji transformacyjnych w ogólniejszym sensie makrospołecznym. Perspektywa partykularystyczna daje nam wprawdzie fascynujący obraz składający się z rozmaitych i niekiedy zaskakujących form uczenia się znaczeń związanych z procesami wytwórczymi i pracą, lecz utrudnia jednocześnie poruszanie się w cyfrowym uniwersum w jasno rysującym się kierunku. Brak linearności, tak znaczącej niegdyś dla idei modernizacji zawartej dyskursach kulturowych społeczeństwa przemysłowego, pozostaje charakterystyczny dla posttechnologicznego świata, w którym wytwarzanie zdigitalizowanego kodu staje się istotniejsze niż „analogowa” z definicji czynność pracy manualnej, wspomaganej tradycyjną technologią maszynową.

Zaburzenie relacji pomiędzy kategorią pracy i jej zaprzeczeniem dotyczy przede wszystkim systemu organizacji tej pierwszej w świecie cyfrowych technologii. Narzędzia informatyczne i Sieć internetowa oplatająca współcześnie każdy, nawet ten niezamieszkany, zakątek globu zezwala na pracę zdalną bez niezbędnej niegdyś infrastruktury wiążącej pracownika z lokalnością.

${ }^{24}$ Jak zauważa dalej Sloterdijk, Nietsche przewiduje, że konflikt przyszłości w kontekście humanizmu zasadzał się będzie pomiędzy zwolennikami dwóch przeciwstawnych obozów tych, którzy postulują minimalizm ludzkiej funkcjonalności oraz tych, którzy chcą ją maksymalizować (a więc np. współcześni transhumaniści). Tamże, s. 22. 
Zerwanie to wymusza na nas jednak równoczesny imperatyw mobilności, zwłaszcza w modelu zglobalizowanej gospodarki i systemów światowych. Procesy związane ze wzrostem mobilności ludzi, towarów i usług wpływają bowiem na zmianę warunków, w jakich wykonywane są dziś zawody niewymagające bezpośrednio lokalnej infrastruktury albo też niezwiązane zasadniczo z lokalną społecznością. Będąc pozbawionym ograniczeń lokalności, a jednocześnie wyposażonym w najnowsze zdobycze techniki teleinformatycznej, szybkie łącze i zestaw narzędzi do transmisji danych, globalny pracownik może w gruncie rzeczy wykonywać swoje obowiązki wszędzie w jednakowy sposób, będąc w swej pracy efektywnym. Jedynym wymogiem wydaje się być w takim przypadku zdolność mobilności i umiejętności szybkiej adaptacji do nowego otoczenia. Cyfrowi nomadzi, jak popularnie określa się ten nowy typ podmiotu w ruchu, poruszają się zatem w świecie z jednej strony dostarczającym im technicznych możliwości do nieprzerwanego pozostawania online i pracy koordynowanej na odległość, z drugiej zaś - wymagającym odrzucenia tego, co mogłoby ograniczać tak ruch, jak i regulującą go zasadę prędkości ${ }^{25}$.

Formowany przez kulturę współczesną cyfrowy nomada realizuje się w specyficznym dla siebie i uwarunkowanym technologicznie stylu życia, w którym cechą dystynktywną jest pewien typowy dla tejże figury balans pomiędzy pracą a czasem wolnym. Jego zachowanie jest możliwe jedynie dzięki wyposażeniu nowoczesnego wagabundy w technologiczne narzędzia zezwalające na wykonanie danego zadania poza infrastrukturą, a co za tym idzie - również poza systemem zależności cechującej lokalne porządki ekonomiczne i społeczne. Cyfrowy nomada, uwolniony od czynników hamujących personalny rozwój zawodowy, pracować może wszędzie i nigdzie zarazem (jeśli przywołamy koncepcję „nie-miejsca” Marca Augé). Organizacja czasu pracy i miejsca jej wykonywania jest w tym przypadku silnie zindywidualizowana, choć wykazuje też pewne cechy wspólne, jeśli zwrócimy uwage na aspekt wizerunkowy tych, którzy do cyfrowego nomadyzmu nie tyle są zmuszeni okolicznościami losu lub ekonomicznymi uwarunkowaniami, ale wybierają taki styl życia uznając go za synonim nowoczesności. Wiąże się zatem omawiane zjawisko z fenomenem współczesnej turystyki, zwłaszcza tej jej odmiany, która posiada silne nacechowanie medialne dzięki współczesnym serwisom społecznościowym promującym obraz wiecznie podróżującego ego. Ci zatem, których stać na stanie się ruchomym podmiotem w cyfrowym uniwersum mogą kształtować swój czas pracy swobodnie, manipulując przekazem płynącym z ekranu smartfona. Problem jednak w tym, że owi podróżnicy będąc obecni w rozmaitych i najbardziej egzotycznych okolicznościach,

${ }^{25}$ G. Deluze, F. Gautarri, Nomadology: The War Machine, Seattle 2010. 
nie są najczęściej zainteresowani miejscem, w którym na moment się zatrzymali. Jak uświadamia nam między innymi Caren Kaplan, ten rodzaj turystyki jest istotnym czynnikiem reprodukującym obecnie lokalne nierówności społeczne, zakładając, że omawiany typ turysty reprezentuje przedstawiciela społeczeństw zachodnich podróżującego po krajach rozwijających się ${ }^{26}$. Wymuszona przez sektor turystyczny i oczekiwana ze strony samych turystów transformacja lokalnych ekonomii dotyka przede wszystkim takich obszarów, jak rynek nieruchomości. Nowo wybudowane hotele zastępują tym samym strukturę starej zabudowy, wypychając jednocześnie mieszkańców na obrzeża. Istotnie, do pogłębiania się wspomnianych nierówności w tym sektorze przyczyniają się współcześnie technologie cyfrowe, szczególnie takie aplikacje, jak Airbnb. Dzięki niej każdy posiadacz mieszkania czy domu może wynajmować krótkoterminowo nie tylko całą nieruchomość, lecz także pojedyncze pokoje turystom wyszukującym jak najtańszego lokum, a jednocześnie samemu szybko podreperować domowy budżet. Przykładem negatywnego wpływu, jaki Airbnb odciska w tkance miejskiej, może być bieżąca sytuacja w Barcelonie i Sewilli. Te dwa hiszpańskie miasta cieszą się w ostatnich latach dużym zainteresowaniem ze strony turystów z różnych zakątków świata. Zwłaszcza podczas takich wydarzeń, jak obchody Wielkiego Tygodnia w Sewilli, kiedy to ulice miasta przemierzają barwnie prezentujący się na zdjęciach zakapturzeni członkowie bractw religijnych, nietrudno ulec wrażeniu, że liczba turystów znacząco przewyższa liczbę mieszkańców. Będący skutkiem popularności tych miejsc, jako destynacji turystycznych, gwałtowny wzrost cen nieruchomości w centrum Sewilli i Barcelony, wypchnął sporą część uboższych mieszkańców do innych dzielnic, w których w przeciągu kilku lat zmuszeni zostali do zmiany miejsca zamieszkania na skutek procesów gentryfikacyjnych lub też jako młodzi uczestnicy rynku pracy w wieku 20-30. lat nie są w stanie pokryć sami koszty najmu i mieszkają nadal z rodzicami ${ }^{27}$.

Cyfrowy nomadyzm utożsamiany jest zatem z możliwością autokreacji i rozwoju jednostki dzięki elastyczności, jaką daje samodzielne kształtowanie czasu pracy przez pracownika zdalnie wykonującego określone zadania. Spostrzeżenie to nabiera jednak odmiennego znaczenia w kontekście wyłaniających się nowych modeli ekonomii i schematów elastycznego zatrudnienia. Wzorzec określany mianem gig economy (dosł. gospodarka fuch), jak również rozmaite modele współdzielenia własności (sharing economy) wprowadzają do dyskusji na temat struktury zatrudnienia i kształtu pracy nowe, nie zawsze optymalne z punktu widzenia na przykład praw pracowniczych

\footnotetext{
26 C. Kaplan, Questions fo Travel: Discourses of Displacement, Durham - London 1996.

27 https://www.theguardian.com/technology/2020/feb/20/soaring-rents-and-noisy -parties-how-airbnb-is-forcing-out-barcelona-locals (09.05.20)
} 
rozwiązania ${ }^{28}$. Gig economy wymaga bowiem zniesienia formalnych podstaw zatrudnienia, $\mathrm{w}$ postaci na przykład umów o pracę, na rzecz systemu elastycznego pod względem prawnym systemu zatrudniania wysoko wykwalifikowanych specjalistów w momencie zaistnienia takowej potrzeby, jak na przykład w najprostszym sensie specjalistów od oświetlenia, czy nagłośnienia w przypadku festiwali muzycznych (stąd to potoczne określenie). Mówiąc prościej, freelancerzy - wąsko wyspecjalizowani pracownicy techniczni, artyści i inni twórcy o unikalnych zdolnościach - poddani zostają reżimowi rynku umów krótkoterminowych, nie dającemu im gwarancji zatrudnienia ani stabilizacji zawodowej, lecz dostarczającemu z drugiej strony innych rzekomych zalet. Przedstawiana jako sytuacja, w której wygrywają obie strony (win-win) gig economy ma w przekonaniu apologetów deregulacji gospodarki oferować wolność i szereg możliwości samorealizacji pracownikom świadomym swej kompetencyjnej wartości i nie będącym zainteresowanym pracą na tradycyjny etat lub nie będącym do jej wykonywania zdolnymi z innych względów. Będąc uosabiana z progresywną organizacją pracy, gospodarka tego typu znajduje jednak wielu zwolenników, a jej elementy są implementowane w różnej skali na całym świecie. Na przykład, jedynie warto przypomnieć, iż zgodnie z przewidywaniami raportu formy Intuit z 2010 roku, w Stanach Zjednoczonych w najbliższym czasie około $40 \%$ pracowników stanowić będzie grupę niezależnych wykonawców i freelancerów ${ }^{29}$. Natomiast w Wielkiej Brytanii w roku 2019 9,6\% populacji (czyli 4,7 mln osób) przynajmniej raz w tygodniu pracowało w sferze gig economy ${ }^{30}$. Zgodnie $\mathrm{z}$ wytycznymi dokumentu Intuit, tendencja ta zbiega się z szeregiem innych procesów makrogospodarczych i społecznych, stanowiąc jeden z ważniejszych czynników głębokiej transformacji poszczególnych sfer życia w świecie zachodnim w nadchodzących dekadach ${ }^{31}$. Debata na temat zmian w sposobie pracy, wynikających między innymi z szerokiego zastosowania technologii mobilnych, toczy się $\mathrm{w}$ wielu kontekstach lokalnych, niemniej wyrażany jest w niej także ważny dla cyfrowego nomadyzmu problem translokalnych postaci sieci współpracy, możliwych dzięki tymże technologiom i odejścia od przypisania do przestrzeni biurowej pracy intelektualnej i kreatywnej ${ }^{32}$. Trudno się

${ }^{28}$ Termin ten niekiedy bywa też tłumaczony jako gospodarka zadaniowa lub praca platformowa.

${ }^{29}$ https:/ / qz.com/65279/40-of-americas-workforce-will-be-freelancers-by-2020/ (09.05.20)

30 Tygodnik Gospodarczy PIE, 12 marca 2020, s. 4.

31 D.D. Green i in., Fueling the Gig Economy: A Case Study Evaluation of Upwork.com, Managment and Economics Research Journal, 2017, 20, s. 109.

${ }^{32}$ Ten aspekt $\mathrm{z}$ kolei wiąże się $\mathrm{z}$ wprowadzanym $\mathrm{w}$ niektórych krajach na wielką skalę systemem ratingowym (jak np. System Kredytu Społecznego w Chinach). Od notowań pracownika $\mathrm{w}$ takim systemie zależy nie tylko pozycja w środowisku innych specjalistów, ale także ocena 
dziwić, że popularność wskazanego wyżej modelu rośnie przede wszystkim $\mathrm{w}$ takich grupach zawodowych, jak pracownicy branży IT, grafika komputerowa, programowanie, marketing, public relations, czy architektura i design. Grupy te łączy obecnie przede wszystkim zbliżony charakter wykonywanych zadań, polegający na wytwarzaniu nie tyleż materialnych przedmiotów, co wysoce złożonych idei, jak również powszechne zastosowanie cyfrowych i usieciowionych narzędzi pracy.

To właśnie sieć cyfrowych połączeń oraz sterujące przepływem w niej informacji algorytmy wydają się być kluczową kwestią w rozpatrywaniu związku cyfrowego nomadyzmu oraz gig economy jako czynnika formującego wyłaniający się w przeciągu ostatnich lat schemat społeczeństwa posttechnologicznego. Paradoks tej sytuacji, w której wysoki stopień zaawansowania narzędzi cyfrowych oraz względnie niski stopień rozumienia ich funkcjonowania końcowego użytkownika konsumującego jedynie wybrane aspekty ich użyteczności, rodzi szereg nowych zjawisk w sferze społecznych interakcji bazujących na wspomnianych narzędziach. Społeczeństwo sieci jest zatem w tym świetle nie tyleż zespołem więzi wysokiej klasy specjalistów, lecz częściej stanowi ono zbiór ludzi połączonych co prawda cyfrową pępowiną z globalnym systemem informacyjnym, jednak nie posiadających tak wysublimowanych kompetencji, aby móc bezpośrednio kształtować technologiczną rzeczywistość, w której uczestniczą. Niezaprzeczalny pozostaje jednak fakt, że procesy zmuszające nas do pracy w formacie krótkoterminowym stanowią istotny czynnik kształtujący technologicznie nasyconą codzienność coraz większej grupy ludzi. Zwłaszcza w kontekście ekonomii współdzielenia (sharing economy) twierdzenie to nabiera głębszego sensu. Rosnąca popularność i zyski takich firm jak Uber, zajmujących się oferowaniem usług (w tym przypadku transportowych) przy współudziale ludzi nie posiadających specjalistycznych licencji i wykształcenia, sprawia, że kwestia zdolności do wytwarzania nowych idei i innowacyjności większości uczestników tego systemu schodzi na dalszy plan. Kluczowa staje się natomiast skala zaangażowania w takowe przedsięwzięcie. Umasowienie technologii, takich jak wybrane aplikacje zezwalające na zamówienie przejazdu w dowolnie wybrane przez nas miejsce dzięki wybranemu przez nas spośród innych, posiadających nieco gorszy rating, kierowcę wydaje się być zachęcającą wizją z punktu widzenia wygody użytkownika, co przekłada się na fakt, iż w roku 2019 dla firmy Uber pracowało na całym świecie 3,9 miliona osób, dokonując w su-

zdolności kredytowej dokonywana przez banki, czy wysokość lub brak rozmaitych dopłat ze strony państwa. Na gruncie zachodnim warto natomiast przypomnieć pomysł dwóch amerykańskich przedsiębiorczyń, które zaproponowały wprowadzenie podobnego w swym zamyśle systemu oceny z użyciem aplikacji „Peeple” wszystkich zarejestrowanych użytkowników na podstawie ich internetowych aktywności. 
mie 10 miliardów przejazdów w 65 krajach i 600 miastach (średnio dziennie wykonywano 14 milionów przejazdów) i przyczyniając się do globalnego zysku netto firmy w wysokości 11,3 miliarda dolarów amerykańskich za rok 2018 (gdzie średni miesięczny zysk kierowcy to 364 USD) ${ }^{33}$.

Komercyjny sukces Ubera, co prawda wyhamowywany co jakiś czas przez protesty lokalnych taksówkarzy lub próby wprowadzenia prawnej regulacji funkcjonowania tej globalnej korporacji w wybranych krajach, pozostaje jednak w dłuższej perspektywie niezachwiany. Model biznesowy przyjęty przez Ubera zakłada bowiem skrajne uproszczenie procesu pozyskiwania nowych pracowników i umożliwienie de facto każdemu chętnemu stanie się kierowcą firmy bez zbędnych formalności. Jednym z istotniejszych czynników motywujących podjęcie zatrudnienia jest zaś możliwość swobody w kształtowaniu grafika czasu pracy, autonomia kierowców i brak rozbudowanych prawnych umów wiążących pracownika na stałe z korporacją. Oceniana przez niektórych jako rozwinięcie pracy tymczasowej, dodatkowe źródła dochodów lub przyjemna alternatywa wobec głównego zajęcia jazda własnym samochodem z obcymi ludźmi za, jak się okazuje, nie tak duże pieniądze, mieści się pomiędzy tradycyjną kategorią pracy (tj. niemobilną, uwarunkowaną umową i dostarczającą główne źródło dochodu) a wspomnianym wcześniej pojęciem poważnego czasu wolnego (niesformalizowanego, aczkolwiek wytwarzającego niezaprzeczalnie pewną wartość dodaną). Nie jest oczywiście ona formą rozrywki, lecz nadal działalnością zorientowaną na wykonywanie zadań przypisanych przez system korporacyjny i przynoszących korzyść finansową obu stronom równania. Posiada ona niemniej pewne walory typowe dla czasu wolnego, jak na przykład brak bezpośredniego przymusu wykonywania określonych czynności (lub przynajmniej pozory takiego braku). Tym, co jednak jest w przypadku systemu Ubera znaczące, to fakt, że zarządzanie tym systemem, opartym na aplikacjach mobilnych i sieci teleinformatycznej, zostało obecnie przeniesione na maszyny, a dokładniej rzecz biorąc - algorytmy sterujące pracą kierowców. Ich zadaniem jest koordynowanie tras przejazdów i dobór danego kierowcy do danego pasażera tak, aby ruch dostępnych samochodów był zoptymalizowany pod względem efektywności. Jednym ze skutków zastosowania tego rozwiązania jest pojawienie się pewnych asymetrii dostrzeżonych między innymi przez Alexa Rosenblata i Luke'a Starka ${ }^{34}$.

Rosenblat i Stark zauważają, że praca, której wykonywanie oparte jest na algorytmach stanowi typowe narzędzie stosowane coraz częściej w ramach gig economy. Dokonują oni swojej analizy przypadku kierowców Ubera na podstawie przeprowadzonych $\mathrm{w}$ czasie rzeczywistym badań postów

${ }^{33}$ https://www.businessofapps.com/data/uber-statistics/ [09.05.20].

${ }^{34}$ A. Rosenblat, L. Stark, Algorithmic Labor and Information Asymmetries: A Case Study of Uber's Drivers, International Journal of Communication, 2016, 10, s. 3758-3784. 
publikowanych przez kierowców na poświeconym im forum internetowym w latach 2014-2015. Forum to jest bowiem miejscem wymiany doświadczeń, wskazówek i rad pomiędzy osobami zatrudnionymi przez korporację, dotyczącymi przede wszystkim tego, jak odnieść w niej sukces. Próba badawcza składała się łącznie z 1350 wypowiedzi, poddanych analizie szczegółowej, z wykorzystaniem metodologii jakościowej. Jak się na wstępie okazuje, Uber komunikuje się w ograniczonym stopniu ze swoimi pracownikami, a większa część komunikacji, łącznie z procesem rekrutacyjnym, odbywa się na odległość poprzez wymianę wiadomości mailowych i SMS-ów. Wysoki stopień mechanizacji interakcji firmy ze swoimi pracownikami odsłaniają kolejne spostrzeżenia poczynione przez innych badaczy, nawet pomimo że uwagi wymieniane na zamkniętym forum można uznać za niereprezentatywne dla globalnej populacji kierowców Ubera nie partycypujących w tej formie wypowiedzi. Studium autonomii nowojorskich i londyńskich kierowców Ubera, autorstwa Mareike Möhlmann i Liora Zalmansona, ukazuje, że algorytm firmy nie pozostawia wielkiego marginesu dla możliwości na przykład zakomunikowania przez kierowców problemów pojawiających się $\mathrm{w}$ trakcie jazdy, a automatyzacja interakcji z centralą firmy staje się dla nich w sposób narastający problematyczna i przyczynia do zmniejszenia produktywności ${ }^{35}$. Warto przypomnieć, że firma unika też nazywania swoich kierowców pracownikami, preferując raczej określenia partnerzy (drive-partners), co sugeruje brak relacji nadrzędności typowych dla firm o strukturze hierarchicznej. Rzekomy egalitaryzm relacji zostaje jednak podany w wątpliwość w kontekście ochrony praw pracowniczych i wynikających z tego spraw sądowych wytoczonych korporacji Uber w latach ubiegłych. Oskarżyciele (byli kierowcy firmy) zarzucają korporacji łamanie podstawowych praw chroniących pracowników w aspekcie zdrowotnym lub prawnym (np. przed pozwami wytaczanymi przez niezadowolonych klientów). Deficyty w systemie komunikacji wewnętrznej, niejasny status kierowców, jak też płynna autoidentyfikacja firmy, mieszcząca się pomiędzy byciem jedynie platformą łączącą jednostki o wspólnym interesie i potencjale zawodowym z klientami a pełnoprawną korporacją sprawnie funkcjonującą na szybko rozwijającym się nowym rynku sharing economy, przyczyniają się do szerokiego wykorzystania nowych technologii na różnych płaszczyznach jej działania organizacyjnego ${ }^{36}$. Algorytmiczne zarządzanie stanowi zatem dla Ubera istotne narzędzie wypra-

${ }^{35}$ M. Möhlmann, L. Zalmanson, Hands on the Wheel: Navigating Algorithmic Management and Uber Drivers' Autonomy, Proceedings of the International Conference on Information Systems (ICIS 2017), December 10-13, Seoul, South Korea, s. 1-17.

${ }^{36} \mathrm{~W}$ sprawie sądowej z 2015 roku toczącej się przed jednym sądów w Kalifornii i wytoczonej Uberowi przez grupę pracowników domagających się zaklasyfikowania ich jako pracowników, firma ta przyjęła linię obrony mówiąc, iż zajmuje się jedynie licencjonowaniem oprogramowania. 
cowywania zysku na podstawie rozmaitych źródeł danych, jak na przykład wykorzystanie danych topograficznych $\mathrm{w}$ dokonywaniu progresywnej wyceny stawek za przejazd $\mathrm{w}$ poszczególnych dzielnicach tego samego miasta (surge pricing). Jakkolwiek asymetria na linii kierowcy/zarząd dotyczy w najbardziej widoczny sposób sfery komunikacji, Rosenblat i Stark pokazują, że problem ten dotyczy całości relacji kształtujących strukturę Ubera, głównie poprzez wewnętrzne mechanizmy zautomatyzowanego ratingu i nadzoru kierowcó $w^{37}$. Będąc zależnym od liczby zdobytych i nadawanych przez mniej lub bardziej zadowolonych klientów gwiazdek, kierowcy stają się integralną częścią systemu pracy algorytmicznej, w którym postulowana przez firmę ich autonomia jako podmiotu nowego typu ekonomii zostaje zderzona ze sprzeczną z tym twierdzeniem rzeczywistością, a znaczna część kwestii decyzyjnych przeniesiona zostaje na algorytm zarządzający.

Praca algorytmiczna budzi obecnie szereg kontrowersji w związku z wpływem, jaki wywiera ona na ludzi pracujących coraz częściej w systemach zautomatyzowanych, nierzadko też wprowadzających dane rozwiązania z użyciem sztucznej inteligencji. Nie chodzi tu zresztą tylko o konsekwencje psychologiczne takiego stanu rzeczy, choć kierowcy Ubera przyznają, że odczuwają w coraz większym stopniu poczucie osamotnienia, dehumanizacji i izolacji ${ }^{38}$. Jak zauważają w swych badaniach Min Kyung Lee, Daniel Kusbit, Evan Metsky i Laura Babish, ważniejszy staje się bowiem, zauważalny obecnie, rozrost formatu algorytmicznego w odniesieniu do wielu innych sfer zawodowych, takich jak na przykład inżynierowie pracujący w systemach metra, magazynierzy, bariści w filiach Starbucks, czy dostarczyciele UPS, w przypadku których „oprogramowanie algorytmiczne służy alokacji, optymalizacji i ewaluacji pracy" ${ }^{\prime 39}$. Ten specyficzny tryb pracy koordynowanej i nadzorowanej przez algorytmy pozostaje obecnie w polu dyskusji nie tylko na temat kształtu rzeczywistości w coraz większej liczbie zawodów i przestrzeni pracy, lecz także rysuje wstępnie ramy debaty na temat kierunku rozwoju interakcji człowieka z maszyną. Interakcja człowiek/maszyna dotyka zaś dwóch zasadniczych problemów szczegółowych: 1) zmian zachodzących bezpośrednio $\mathrm{w}$ miejscu pracy ( $\mathrm{w}$ sensie organizacyjnym, przestrzennym, strukturalnym itp.), jak i 2) relacji pomiędzy człowiekiem a maszynami obdarzonymi pewnym stopniem sztucznej inteligencji. Poszukiwanie odpowiedzi

${ }^{37}$ A. Rosenblat, L. Stark, Algorithmic Labor and Information Asymmetries, s. 3772.

${ }^{38}$ M. Möhlmann, O. Henfridsson, What People Hate About Being Managed by Algorithms, According to a Study of Uber Drivers, Harvard Business Review, 2019, August 20; https://hbr. org/2019/08/what-people-hate-about-being-managed-by-algorithms-according-to-a-study-of -uber-drivers [09.05.20].

${ }^{39}$ M. Kyung Lee i in., Working with Machines: The Impact of Algorithmic and Data-Driven Management on Human Workers, CHI '15 Proceedings of the 33rd Annual ACM Conference on Human Factors in Computing Systems, 2015, s. 1. 
dającej nam w nie wgląd stanowi główny cel badań Lee, Kusbita, Metsky i Babish. Na gruncie przeprowadzonej przez siebie analizy jakościowej sposobu funkcjonowania kierowców Ubera i działającej na podobnej zasadzie konkurencyjnej firmy przewozowej Lyft, dochodzą oni do wniosku, że przypisywanie przez algorytm zarządzający ocen i ewaluacja pracy kierowców nie tylko postrzegana była przez niech samych za nieadekwatną do rzeczywistych wyników ich pracy, ale także realnie nieefektywną ${ }^{40}$. Wyrażana przez kierowców niechęć wobec zastosowania zarządzania poprzez algorytm wynikała z kolei z poczucia braku sensowności partykularnych decyzji podejmowanych przez maszynę. Ten właśnie argument przeważał również w będących przedmiotem analizy w rozmowach na forach internetowych i wskazywał na konieczne zmiany w sferze indywidualnych strategii sensotwórczych (tj. nadających znaczenie kolektywnym doświadczeniom współdzielonym przez jednostki).

Deficyty sensu w sferze pracy wydają się obecnie jednym $\mathrm{z}$ tematów podejmowanych na różnych płaszczyznach refleksji, której centralnym problemem są procesy społeczne zachodzące w dobie zmiany technologicznej, liberalizacji gospodarki, czy procesów globalizacyjnych. Najbardziej radykalne stanowisko w tej debacie zajmuje brytyjski antropolog David Graeber, który wyraża przekonanie, iż spora część zawodów i współczesnych form pracy stanowi tak zwaną "pracę bezużyteczną" (dosł. bullshit jobs) ${ }^{41}$. Autor książki Debt: The First 5000 Years definiuje ją jako pracę, która nie wytwarza żadnej nowej jakości, jej sens jest trudny do racjonalnego uzasadnienia, jak też nie przyczynia się ona w żaden sposób do cywilizacyjnego postępu, a raczej wręcz go hamuje. Jest to praca, której „brak nikt by nie zauważył” Jej jedynym celem staje się reprodukowanie systemu, w którym pracownicy bezużyteczni funkcjonują w wymiarze organizacyjnym. Maskują oni jednakże często bezsensowność wykonywanych przez siebie czynności poprzez racjonalizowanie tej sytuacji lub też obierają takie strategie funkcjonowania w swym firmach, urzędach i innych organizacjach, które pozwalają im odnaleźć głębsze znaczenie równolegle i niezależnie $w$ innych sferach życia. Barwnym przykładem tego ostatniego jest przypadek pewnego urzędnika państwowego z Hiszpanii, którego ukarano w 2016 roku za samowolne oddalenie się z miejsca pracy i nie pojawianie się niej w przez 6 kolejnych lat ${ }^{43}$. Czas ten poświecił on studiowaniu dzieł Barucha Spinozy, w którego filozofii ów urzędnik stał się ekspertem. Pikanterii tej historii dodaje fakt, iż jego nieobecność odkryto dopiero w momencie, gdy miano mu wręczyć nagro-

40 Tamże, s. 8 .

${ }^{41}$ D. Graeber, Bullshit Jobs: A Theory, New York 2018.

${ }^{42}$ Tamże, s. 17.

${ }^{43}$ https://www.timesofisrael.com/spanish-engineer-who-skipped-work-for-6-years -was-studying-spinoza/ [12.05.20]. 
dę za długoletni staż pracy. Przypadek ten nie jest, jak się możemy jedynie domyślać, odosobniony. Do zawodów mieszczących się w rekonstruowanej przez Graebera formule zalicza on bowiem takie grupy, jak: specjaliści od public relations, lobbyści korporacyjni, konsultanci finansowi, specjaliści od marketingu, ale też najemni pracownicy w sferze rozrywki, zawodowi organizatorzy czasu wolnego, urzędnicy, telemarketerzy i tym podobni. Odróżnić jednak należy pracę wykonywaną wprawdzie przy niskich płacach, w złych warunkach i pozbawioną społecznego uznania, lecz jednak przydatną, od pracy bezużytecznej. Praca określana przez Graebera mianem beznadziejnej (dosł. shit jobs) skupia zazwyczaj ludzi wywodzących się z klasy robotniczej, opłacanych godzinowo, zaś praca bezużyteczna (bullshit jobs) zazwyczaj wykonywana przez przedstawicieli klasy średniej opłacana jest poprzez stałą pensję $^{44}$. Pojęcie sensu w kontekście pracy, działania społecznego, czy wreszcie wytwarzania nabiera zatem coraz wyraźniej wymiaru klasowego i może stać się jednym z kluczowych znaczników nowych społecznych nierówności już w niedalekiej przyszłości.

Nietrudno zauważyć, że współczesne warunki społeczno-ekonomiczne generują z wielkim pietyzmem pola, w których praca bezsensowna może trwać i być multiplikowana. Tendencji tej sprzyja postępująca mechanizacja wybranych zawodów i coraz powszechniejsze zastosowanie w nich takich technologii, jak na przykład boty internetowe. Stanowiska pozbawione społecznej wagi, nie wytwarzające ani materialnych efektów, ani też żadnych znaczących idei, mnożone są $\mathrm{w}$ strukturach korporacyjnych, zbiurokratyzowanych aparatach urzędniczych, czy nawet w systemach szkolnictwa wyższego ${ }^{45}$. Bezużyteczność $w$ działaniu uznać możemy również za jedną z kulturowych cech systemu społecznego wyrosłego na gruncie późnej postaci modelu przemysłowego, w którym komponent ludzki traci na znaczeniu wobec elementu maszyny. Wiąże się ona bowiem nie tylko z zamazywaniem i degradacją sensotwórczych praktyk na rzecz mechanicznego w swej naturze wprowadzania danych, segregowania akt i sprzedaży kredytów typu sub-prime, lecz również $\mathrm{z}$ upowszechniającą się akceptacją dla strukturalnej niekompetencji. Kultura niekompetencji jest zaś zjawiskiem właściwym przede wszystkim rozbudowanym strukturom organizacyjnym i dużym instytucjom. To w systemach biurokratycznych ujawnia się bowiem najpełniej milczące przyzwolenie dla niewypełnionych druków, niewysłanych na czas dokumentów, czy bezradnego rozłożenia rąk wobec istotnych pytań ze strony petenta. Może jednak manifestować się ona równie dobrze w instytucjach o mniejszej skali organizacji, aczkolwiek związanych bezpośrednio i zależnych (np. finansowo lub

${ }^{44}$ D. Graeber, Bullshit Jobs: A Theory, New York 2018, s. 23.

${ }^{45}$ http:// dailynous.com/2018/05/08/bullshit-jobs-higher-ed/; https://www.chronicle. com/article/ Are-You-in-a-BS-Job-In/243318 [12.05.20]. 
legislacyjnie) wobec nich zewnętrznych oraz nadrzędnych struktur, a więc także w szkołach lub uniwersytetach.

Poruszony w tym tekście temat sprawczości, tworzenia, pracy i innowacyjności w dobie dominacji technologii cyfrowych stanowi złożony problem wymagający głębszego przyjrzeniu się relacjom łączącym obecnie sferę ICT z modelami organizacyjnymi i kulturą organizacyjną wielu rozmaitych instytucji. Jest to tym istotniejsze, iż wyłaniające się współcześnie tendencje w sposobach zarządzania tymi instytucjami oraz rozmaite technologie wspierające je na poziomie interakcji aktorów społecznych zaangażowanych $\mathrm{w}$ ich funkcjonowanie stają się coraz bardziej zależne od modeli matematycznych, których głównym zadaniem jest nie wspieranie relacji pomiędzy owymi aktorami, lecz maksymalizacja zysków i optymalizacja wydajności. Postępujący proces ekonomizacji poszczególnych sfer życia publicznego rodzi jednak nowe zjawiska społeczne, stanowiące nierzadko formę strategii nie tyleż sprzeciwu, lecz pewną postać adaptacji i twórczej transformacji ograniczeń i uwarunkowań działań jednostek oraz grup. Zjawiska te, w dobie wszechobecnej cyfryzacji, posiadają charakter ",analogowy", to jest odwołują się i bazują na wykorzystaniu w cyfrowym uniwersum pewnych elementów związanych z takimi aspektami, jak praca manualna, rzemiosło, czy sensualna refleksyjność (jako antytezy funkcjonowania w wirtualnej rzeczywistości).

\section{BIBLIOGRAFIA}

Arendt H., The Human Condition, Chicago - London 1998.

Boas F. (red.), General Anthropology, Boston - New York - Chicago - Atlanta - Dallas - San Francisco - London 1938.

Davidson D., Essays on Actions and Events, Oxford 2001.

Deluze G., Gautarri F., Nomadology: The War Machine, Seatlle 2010.

Durkheim E., Zasady metody socjologicznej, Warszawa 1968.

Green D.D., Walker C., Alabulththim A., Smith D., Fueling the Gig Economy: A Case Study Evaluation of Upwork.com, Managment and Economics Research Journal, 2017, 20.

Huizinga J., Homo ludens. Zabawa jako źródto kultury, Warszawa 1985.

Huxley J., Transhumanism, Journal of Humanistic Psychology, 1968, 8(1).

Kaplan C., Questions fo Travel: Discourses of Displacement, Durham - London 1996.

Kyung Lee M., Kusbit D., Metsky E., Dabbish L., Working with Machines: The Impact of Algorithmic and Data-Driven Management on Human Workers, CHI '15 Proceedings of the 33rd Annual ACM Conference on Human Factors in Computing Systems, 2015.

Graeber D., Bullshit Jobs: A Theory, New York 2018.

Lukes S., Durkheim, Warszawa 2012.

Möhlmann M., Henfridsson O., What People Hate About Being Managed by Algorithms, According to a Study of Uber Drivers, Harvard Business Review, August 20, 2019.

Möhlmann M., Zalmanson L., Hands on the Wheel: Navigating Algorithmic Management and Uber Drivers' Autonomy, Proceedings of the International Conference on Information Systems (ICIS 2017), December 10-13, Seoul, South Korea. 
Poser H., Homo Creator - Technik als philosophische Herausforderung, Wiesbaden 2016.

Rosenblat A., Stark L., Algorithmic Labor and Information Asymmetries: A Case Study of Uber's Drivers, International Journal of Communication, 2016, 10.

Schmiede R., Homo faber digitalis? Zur Dialektik von technischen Vortschritt und Arbeitsorganisation, Mitelweg, 2015, 26(24).

Turner V.W., Drama, Fields and Metaphors. Symbolic Action in Human Society, New York 1975.

Tygodnik Gosporaczy PIE, 12 marca 2020.

Sloterdijk P., Rules for the Human Zoo: a response to the Letter on Humanism, Environment and Planning, 2009, 27.

Watts Miller W., Creativity: a key Durkheimian concern and problematic, European Journal of Social Sciences, 2017, 55(2).

https:/ / www.theguardian.com/technology/2020/feb/20/soaring-rents-and-noisy-parties-how-airbnb-is-forcing-out-barcelona-locals

https:/ / qz.com/65279/40-of-americas-workforce-will-be-freelancers-by-2020/

https://www.businessofapps.com/data/uber-statistics/

https:/ / www.timesofisrael.com/spanish-engineer-who-skipped-work-for-6-years-wasstudying-spinoza/

http:/ / dailynous.com/2018/05/08/bullshit-jobs-higher-ed/;https:/ /www.chronicle.com/ article/ Are-You-in-a-BS-Job-In/243318 